\title{
ENERGY EFFICIENT GLAZED OFFICE BUILDING ENVELOPE SOLUTIONS FOR DIFFERENT EUROPEAN CLIMATES
}

\author{
Marco SCANFERLA ${ }^{1}$, Violeta MOTUZIENE ${ }^{2}$ \\ ${ }^{1}$ University of Padua, Padova, Italy \\ ${ }^{2}$ Vilnius Gediminas Technical University, Vilnius, Lithuania \\ E-mails: ${ }^{1}$ marco.scanferla.2@studenti.unipd.it; ${ }^{2}$ violeta.motuziene@vgtu.lt
}

\begin{abstract}
The aim of this study is to show the critical aspects of a completely glazed high rise office building from an energy efficiency point of view in different European climates. The achievable consumptions and the most influential parameters such as glazing U-value, VT/SHGC and shading and their optimal values were investigated. The study has been carried out for a theoretical office building in Italy and Lithuania, representatively of a southern and northern EU climate. The building chosen is representative of all the glazed-simple shape buildings and the analysis of the entirety of the building enables a clear and immediate outcome of global consumptions. Number of DesignBuilder simulations were performed and the annual consumptions are summed with the primary energy criteria. Results show the critical aspects of $100 \%$ WWR buildings: in the coldest climate the main problem is the huge surface of relatively high glass U-value compared with standard walls, while in the warmer one the main efforts need to be done to avoid the summer overheating caused by incoming solar radiation. Finally, it is shown that it is difficult to lower the overall primary energy consumptions below 130 and $140 \mathrm{kWh} / \mathrm{m}^{2}$ a for North-Italy and Lithuania locations respectively. The analysis is focused only in the envelope parameter, thus it is not included renewable energy systems, which can generate higher energy efficiencies.
\end{abstract}

Keywords: office building, different climates, energy efficiency, envelope, glazed facade, shading.

\section{Introduction}

\section{Thermal issues of glazed curtain walls}

Looking at each medium or large city it's easy to realize how many of the new modern buildings are covered with a glazed curtain walls (Fig. 1). This architectural solution is dominating already for decades. Transparent skins provide access to daylight, and natural daylight is one of the leading drivers today of architectural design.

Focusing on the energy savings aspect, the glazed façade is not the best solution. Indeed, using the best windows solutions, the glass U-value will be always 5-8 times higher than a modern standard brick insulated walls and much more solar radiation can enter into the building. Despite of the great success of glazed curtain wall, a tendency against it has grown into the society: experts such as Straube (Straube 2008) and Alex Wilson, founder of Environmental Building News, are against the use of the glass façade, supporting more classical way of building such as concrete brick walls. In literature, examples of unsuccessful glazed buildings are easy to find (De Carli, De Giuli 2007). For example, Dental clinic centre of the
University of Zurich and "Intesa San Paolo" building in the center of Turin which require 78 and $100 \mathrm{kWh} / \mathrm{m}^{2}$ a respectively, only for heating purposes (Iasparra 2009).

In any case, in the last decades the global awareness of this problem strongly pushes the development of glazed curtain wall buildings. Indeed, in the last generation of glazed building, many of them were classified as low energy ones by green certifications systems such as LEED and BREEAM. The most sustainable and famous is "The Edge" office building in the Netherlands: it is asserted that the level of final energy consumption of the building will

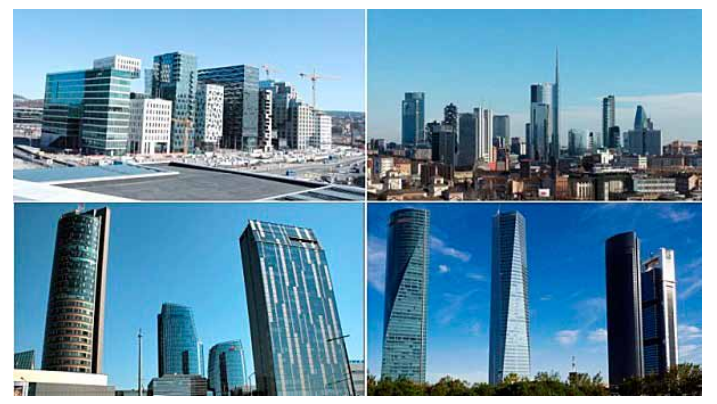

Fig. 1. Oslo (Norway), Milan (Italy), Vilnius (Lithuania), Madrid (Spain) 
vary between 0.3 and $40.7 \mathrm{kWh} / \mathrm{m}^{2}$ a depending on the availability of the renewable energy supply by the PV production. It should be noted, that such consumption is reached using renewables - solar energy for electricity production and ground heat pumps for heating and cooling (Buildup European Journal 2017).

Many of the study found in literature about the totally glazed buildings, focused in one particular specific aspect such as natural ventilation on double skin (Kong et al. 2016), thermal collector as shading system (PalmeroMarrero, Oliveira 2006; Etzion, Erell 2000). A lack of information was found in the general fields of reference building for comparison, primary energy requirements, and energy savings. Furthermore, the complex analysis in the studies implies building shapes much different: either small (Bruno et al. 2015) or big (Bellia et al. 2013); or even just small part of them as a single room (Grynning et al. 2014), thus to conclude a general result is difficult.

The aim of this study is to show the critical aspects of a completely glazed high rise office building from an energy efficiency point of view in different European climates (Southern - Italy and Northern - Lithuania). In addition, to analyze, if it is possible to reach NZEB (Nearly Zero Energy Building) energy demand, without employing renewables.

In this article, after a brief definition of energy requirements for reference buildings, an analysis of the parameters involved in the energy savings aspects of an office building is carried out, and finally a simple case study was analyzed. The focus on the overall annual primary energy demand and on the complete building in its entirety gives a general idea of how much can be the energy requirements for an high-rise glazed buildings (without usage of renewables). In addition, it gives an idea, which are the critical envelope ding on the climate. parameters that influence the energy requirement, depen-

\section{NZEB definition}

The definition of NZEB (Nearly Zero Energy Building) is not unique across the EU. The EBPD recast of 2010 (Directive 2010/31/EU) gives strictly directive about deadline, but no clear requirements about building consumption, letting each EU country decide for itself. Therefore, differences across the EU for the non-residential NZEB primary energy requirements vary from $25 \mathrm{kWh} / \mathrm{m}^{2} \mathrm{a}$ (Denmark) to $270 \mathrm{kWh} / \mathrm{m}^{2} \mathrm{a}$ (Estonia) and these are numbers taking into account renewable energy usage in the building (as required by EPBD).

\section{Envelope parameters}

During the first step of the current study, a profound literature research about the different NZEB parameters state-ofart was carried out. The literature review was not focused just on highly glazed buildings, in order to discover which are the best values for each of the following parameters depending on the northern or southern European climate.

\section{$W W R$}

It is shown in table 1.2 the recommended glazing area for office building is included in the range of $20-40 \%$ (Table 1) with a higher value for the northern locations. The south oriented façades should be considered as an exception because they usually have different value from the other ones.

Many articles showed that $100 \%$ glazed building has always a higher energy demand than standard isolated building. Moreover, with accurate adjustments in all the other façade parameters, it was possible to lower the energy demand of a total glazed building up to $15 \%$ higher than in a reference building (with 30\% WWR) (Poirazis et al. 2008).

Table 1. Optimum WWR values, related to the article in which they were proposed

\begin{tabular}{|c|c|c|c|c|}
\hline & \multicolumn{2}{|c|}{ Northern Climate } & \multicolumn{2}{|c|}{ Southern Climate } \\
\hline \multirow[t]{2}{*}{ (Susorova et al. 2013) } & 0.8 & $\mathrm{~S}$ & \multirow[t]{2}{*}{0.4} & \\
\hline & Low & $\mathrm{N}$ & & \\
\hline \multirow[t]{2}{*}{ (Goia 2016) } & 0.56 & $\mathrm{~S}$ & 0.27 & $\mathrm{~S}$ \\
\hline & 0.4 & E,N,W & 0.35 & E,N,W \\
\hline (Liu et al. 2015) & & & 0.4 & \\
\hline \multirow[t]{2}{*}{ (Motuziene, Juodis 2010) } & 0.2 & S,E,W & & \\
\hline & $0.2-0.4$ & $\mathrm{~N}$ & & \\
\hline (Inanici, Demirbilek 2000) & $0.5-0.7$ & $\mathrm{~S}$ & 0.25 & $\mathrm{~S}$ \\
\hline
\end{tabular}

Note: The two different columns indicate the location in which the value of optimal WWR was simulated. Usually the values were different depending on the façade orientation and or on the season (Kontoleon, Bikas 2002). S, E, N, W are representative for the four compass points. 


\section{Shading}

Results of the shading literature review highlight that regarding southern European climates the use of a shading system is a must and it is more efficient if the devices are dynamic and automatically controlled (Nielsen et al. 2011; Ascione et al. 2016). Moreover, the presence of both internal and external shading system could be an optimal solution. On the other hand, in the northern climates, the energy savings obtained thanks to the installation of a shading devices appear lower than in the southern climate (Bellia et al. 2013); nevertheless, if the purpose is achieving an NZEB, shading systems should be installed in the northern climate office buildings too (Tzempelikos, Athienitis 2007). But they should not be installed without an accurate investigation of each single case and strategy.

It was found that with an automatic shading system with the appropriate strategy, global annual energy savings can be estimated between $9-16 \%$ in the colder climates, up to $20 \%$ in the warmer ones. Table 2 .

\section{Envelope thermal resistance}

The development of envelope research has brought to the conclusion that there are some parameters that characterize the envelope performance, which cannot be optimized with the same value both in Continental and Mediterranean climate.
As suggested by (Bruno et al. 2015) in a research for the optimization of a passive house in Mediterranean climate, there are some main differences between the two climate: large transparent surfaces with low solar gain coefficients south facing are penalizing for the excessive cooling requirements in warm climates. Different insulation thicknesses are required for continental and Mediterranean climate. In the first one, to reduce the heating energy demand, even more than $20 \mathrm{~cm}$ of insulation is required. While in the second climate, thickness of isolation of $10 \mathrm{~cm}$ could be sufficient to compensate the reduction of solar heat gain during winter. In any case to achieve NZEB objective very low U-value for the walls are required. In Table 3 some suggestions from literature are reported. Since they can be much different because of building shape, walls materials and layers, orientations, and so on, in table 4 U-value national standards are reported for the two involved locations.

\section{$V T$ and $S H G C$}

An important characteristic of the window is not just its U-value, but also solar heat gain coefficient (SHGC), responsible for solar heat gains and visible lighting transmittance coefficient (VT or VLT), responsible for daylighting in the room. There is no linear correlation between these two parameters, but as a rule, when SHGC is decreasing, VT is decreasing as well. Depending on the window construction, this negative effect differs.

Table 2. Percentage values of energy savings thanks to a shading system. Values are reported with the locations in which the simulations/measures were carried out. Each value is related to the author who proposed it

\begin{tabular}{|l|l|l|l|l|}
\hline & \multicolumn{2}{|c|}{ Northern climates } & \multicolumn{2}{c|}{ Southern climates } \\
\hline (Bellia et al. 2013) & & & $8-20 \%$ & Milan-Palermo \\
\hline (Nielsen et al. 2011) & $16 \%$ & Denmark & & \\
\hline (Tzempelikos, Athienitis 2007) & $9-16 \%$ & Montreal & & \\
\hline
\end{tabular}

Table 3. Suggested envelope value corresponding with the related source

\begin{tabular}{|c|c|c|c|}
\hline & References & Northern Climate & Southern Climate \\
\hline \multirow{3}{*}{$\begin{array}{l}\text { Walls } \\
\text { U-value }\end{array}$} & (Ascione et al. 2016) & & 0.18 \\
\hline & (Buonomano et al. 2016) & & 0.23 \\
\hline & (Yu et al. 2015) & $\leq 0.40$ & $\leq 1.0$ \\
\hline \multirow{3}{*}{ Roofs } & (Ascione et al. 2016) & & 0.16 \\
\hline & (Buonomano et al. 2016) & & 0.23 \\
\hline & (Yu et al. 2015) & $\leq 0.45$ & $\leq 0.7$ \\
\hline
\end{tabular}

Table 4. National U-value Standards for each building part

\begin{tabular}{|l|l|l|}
\hline \multicolumn{1}{|c|}{ Standards } & \multicolumn{1}{|c|}{ LT (Northern climate) } & \multicolumn{1}{c|}{ ITA (Southern climate) } \\
\hline Walls U-value & $0.1-0.14$ & $0.24-0.43$ \\
\hline Windows U-value & $0.7-1.1$ & $1.10-3.00$ \\
\hline Slabs & $0.08-0.12$ & $0.24-0.44$ \\
\hline Roofs & $0.08-0.12$ & $0.20-0.35$ \\
\hline
\end{tabular}


SHGC is not one of the most important parameters when a building with standard WWR is analysed, but in this case is different. This ratio (SHGC/VT) has a strong impact on the cooling requirements, because less solar gain means less cooling energy, on the heating, because more solar gain means less heating energy, and finally in the lighting, because higher values of VT mean that less artificial lighting is necessary (Poirazis et al. 2008). Optimal values of SHGC for a non-glazed high performance building located in the north of Italy is around 0.69 (Bruno et al. 2015). Moving towards $100 \%$ WWR values, things change dramatically: in a research based on a Sweden totally glazed building the optimal value is around 0.27 . The ideal case is to have as high as possible VT coefficient and as small as possible SHGC value. The energy and daylighting efficiency of glazing is characterized by $\tau_{1} / \mathrm{g}$. When this relation is less than 1, glazing does not ensure sufficient daylighting and if relation is more than 1.55 , such glazing is considered as very efficient (Motuzienè, Juodis 2010). The high-performance glazing products available today, when combined with effective daylighting strategies, have the potential to deliver high-performance façades, which maintain the glazed area while improving energy performance and occupant comfort.

\section{Methodology}

In order to give an answer to the problem highlighted at the end of the first chapter, the research methodology includes the following steps (see Fig. 2):

Annual simulations were run with the software Design Builder $\mathrm{v} 3.4$, paying attention that the comfort parameters were always in the allowed range. A fuel breakdown with the final energy for each area is given as an output. Assessment was performed in terms of primary energy (as required by EPBD), assuming that heat is produced from natural gas and electricity from non-renewable energy sources. Electricity demand includes the loads powered by electrical energy: cooling, room equipment, lighting, fans and pumps (fans and pumps are not often included in literature (Goia 2016), but as it can be seen their contribute cannot be neglected); while gas demand - just heat for heating purposes. According to IINAS (2015) development of PEF study, the primary energy factors considered are 2.46 for electricity (mixed) and 1.24 for natural gas.

\section{Case study}

A medium-high rise theoretical building has been chosen as reference building (Fig. 3). It has been preferred not to choose extraordinary sizes in order to include in the simulation results all the medium-rise buildings around 15-25 storey. A simple building shape has been chosen: prism with square bottom geometry. The absence of protrusion and the simple shape contribute to reduce the heat loss (Lylykangas 2009). The dimensions for the reference building have been chosen 30x32 m, and later the height has been chosen depending on the shape factor. Even if the perfect plan shape is the circular one, which allows further $10 \%$ savings more than a square bottom shape (Hernandez 2011). Although this implies lower energy consumption, this solution has not been adopted because the most part of the building have a square or rectangular plan. Also, this office configuration is an advantage considering the purpose of the study. In this way, parameters coming from different facades orientations can be compared. For instance, it can be evaluated if cooling consumption in south oriented office or heating consumption in the north oriented office are more influent on the global energy consumption.

Finally, an optimization study has been conducted in order to choose the building height (Feng et al. 2016). Having the floor plan geometry and chosen a typical storey height of medium-rise building of $3.5 \mathrm{~m}$, it is clear from the graph (Fig. 4) that above 15 storey building's shape factor decreases insignificantly. Thus, the solution, which has been chosen, is 20 story; this corresponds to $70 \mathrm{~m}$ height and a 0.143 shape factor.

The total building floor area is $18463 \mathrm{~m}^{2}$. The roof was set according to the national U-value standards: 0.22 and $0.11 \mathrm{~W} / \mathrm{m}^{2} \mathrm{~K}$ for Italy and Lithuania respectively.

When choosing HVAC system for a model, it was taken into its suitability for northern and southern European

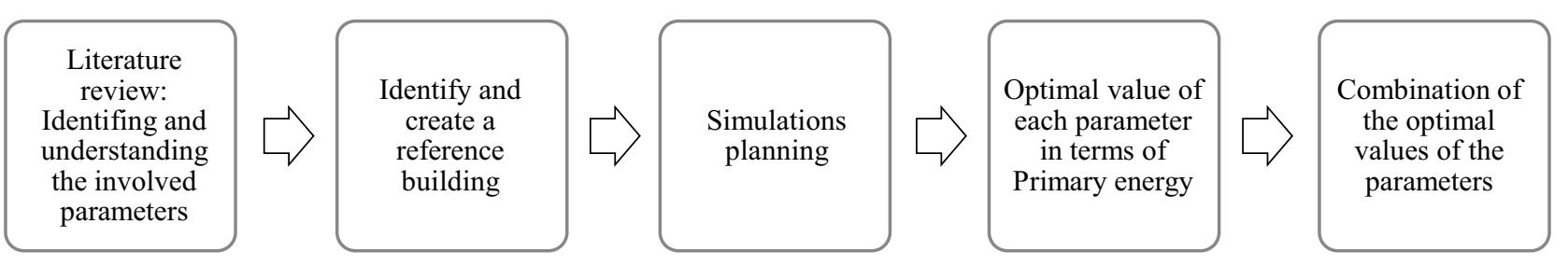

Fig. 2. Research methodology principal scheme 

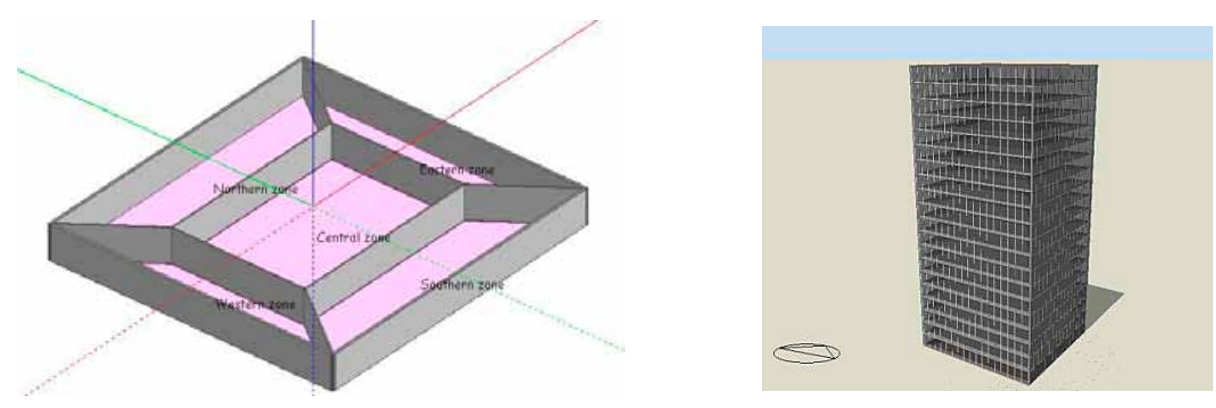

Fig. 3. Typical floor plan and complete building render (model view from DesignBuilder)

climates was taken into account. A fan coil HVAC system was chosen. The operation period for the boiler and the chiller are selected according to the Italian and Lithuanian standards. The efficiency of gas boiler -0.89 , chiller COP 5.5 , heat recovery efficiency -0.75 . Specifications of the building services settings as well as internal loads are given in Table 5, based on specifications suggested in EN 15251:2008 and EN ISO 13790:2008.

\section{Simulation planning}

In literature the main parameters which can influence a single skin curtain wall were found (Lam et al. 2015):

- glazing U-value (Ugl);

- U-value of the spandrel panel (Usp);

- U-value of frame (Ufr);

- solar heat gain coefficient (SHGC);

- visible transmittance (VT);

- infiltration rate;

- window wall ratio (WWR);

- depth and inclination of overhang.

In this paper some modifications are reported in order to make the simulations process as lean as possible without losing any important data. First, glazing U-value and frame $\mathrm{U}$-value are analysed together because there is no interest to have different simulation for those two parameters. Furthermore, in the national standard the total windows $\mathrm{U}$-value is mentioned and not the glazing and the

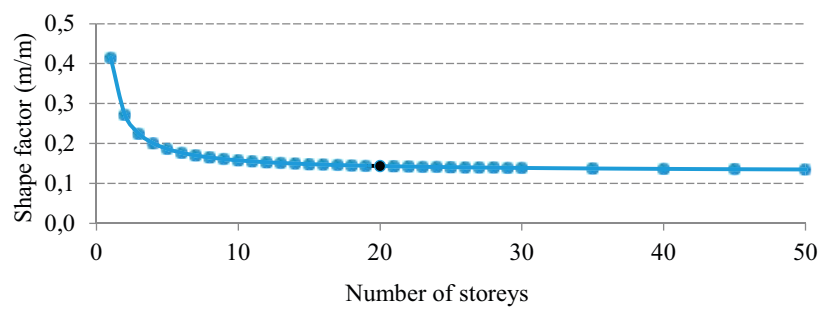

Fig. 4. Optimization study for the height choice

frame U-values individually. Finally, there is no spandrel window, thus the glazing U-value, the frame U-value and the spandrel U-value are all assembled in window U-value parameter. Second, Solar Heat Gain Coefficient and Visible Transmittance are analysed together, because their relation enables to select efficient solutions both in terms of energy and in terms of daylighting. Third, infiltration rate through the windows is kept constant, as well as WWR $=100 \%$. Finally, the type and geometry of the shading system are analysed.

\section{U-Value}

In both Italian and Lithuanian standards the windows U-value for a NZEB is given. Thus, in the simulation this parameter will be changed starting from the value given from the national standards to higher performances values (Table 6).

Table 5. Settings for HVAC, internal loads, and lighting for the zone office rooms

\begin{tabular}{|l|c|c|c|c|c|c|c|c|}
\hline & \multicolumn{2}{|c|}{$\begin{array}{c}\text { Temperature } \\
\text { set-point }\left({ }^{\circ} \mathrm{C}\right)\end{array}$} & \multicolumn{2}{c|}{ HVAC } & \multicolumn{2}{c|}{ Internal loads } & \multicolumn{2}{c|}{ Lighting } \\
\hline & Heating & Cooling & $\begin{array}{c}\text { Mechanical } \\
\text { Ventilation } \\
(1 / \mathrm{s} \text { person) }\end{array}$ & $\begin{array}{c}\text { Heat } \\
\text { recovery } \\
\text { efficiency }\end{array}$ & $\begin{array}{c}\text { Equipment } \\
\left(\mathrm{W} / \mathrm{m}^{2}\right)\end{array}$ & $\begin{array}{c}\text { People } \\
\left(\mathrm{W} / \mathrm{m}^{2}\right)\end{array}$ & $\begin{array}{c}\text { Installed } \\
\text { power } \\
\left(\mathrm{W} / \mathrm{m}^{2}\right)\end{array}$ & $\begin{array}{c}\text { Illuminance } \\
\text { set-point } \\
(\text { lux })\end{array}$ \\
\hline $\begin{array}{l}\text { Occupancy } \\
\begin{array}{l}\text { Mon-Fri } \\
7 \text { am-6 pm }\end{array}\end{array}$ & 22 & 24 & 10 & 0.75 & 10 & 11.5 & 7.5 & 500 \\
\hline Non occupancy & 12 & 35 & 0.0 & 0.75 & 0.0 & 0.0 & 7.5 & 0 \\
\hline
\end{tabular}


Table 6. The U-values are expressed in $\mathrm{W} / \mathrm{m} 2 \mathrm{~K}$

\begin{tabular}{|l|l|l|l|l|l|}
\hline \multicolumn{1}{|c|}{ Simulations } & 1.4 & 1.2 & 1.0 & 0.8 & 0.6 \\
\hline Location & & & & & \\
\hline Italy-Padova & $\checkmark$ & $\checkmark$ & $\checkmark$ & $\checkmark$ & $\checkmark$ \\
\hline Lithuania-Vilnius & & $\checkmark$ & $\checkmark$ & $\checkmark$ & $\checkmark$ \\
\hline
\end{tabular}

\section{$V T$ and $S H G C$}

Since there are no standard requirements for SHGC and VT, the simulations input data will be the same in Italy and Lithuania. In the VT and SHGC simulations, all facades are kept with the same values. The values of SHGC are chosen in order to have some alternatives during the simulations, while, the DesignBuilder library was investigated in order to find reliable VT values existing in real windows (Table 7). Furthermore, to avoid too many simulations, the glazing U-value was kept constant at $0.8 \mathrm{~W} / \mathrm{m}^{2} \mathrm{~K}$.

Table 7. SHGC, VT and VT/SHGC values used in the simulations

\begin{tabular}{|l|l|l|l|l|l|}
\hline SHGC & 0.9 & 0.7 & 0.5 & 0.3 & 0.1 \\
\hline VT & 0.95 & 0.8 & 0.6 & 0.4 & 0.15 \\
\hline VT/SHGC & 1.06 & 1.14 & 1.20 & 1.33 & 1.50 \\
\hline
\end{tabular}

\section{External shading}

The process to choose the alternatives of external shading was based on two criteria. First it was investigated which shading types allow to stop the solar gain income during the summer, when the sun azimuth angles are higher (Grynning et al. 2014). Second, the system should allow as much as possible incoming solar radiation during the winter.

The first task to avoid summer overheating, the second one to reduce the heating requirements. Again, a too high number of simulation, during this step, the glazing U-value, the SHGC and the VT were kept constant at $0.8 \mathrm{~W} / \mathrm{m}^{2} \mathrm{~K}$, $0.5,0.5$ respectively.

\section{Overhang}

In Table 8 there are the two steps of simulations for the overhangs shading system. As it is known from the literature, it does not make sense to have any shading system on the north façade. Actually, the direct solar radiation is lightly present in the earliest and latest hours of summer days. The absence of shading system allows the highest amount of natural lighting.

Table 8. Overhang shading system cases

\begin{tabular}{|l|l|l|l|l|l|}
\hline \multicolumn{2}{|l|}{} & \multicolumn{4}{|c|}{ Projection (m) } \\
\hline 1 & East South West Façades & 1.0 & 1.5 & 2.0 & 3.0 \\
\hline 2 & South Façade & 1.0 & 1.5 & 2.0 & 3.0 \\
\hline
\end{tabular}

\section{Louvers}

The horizontal louvers are located along the whole windows as shown in Figure 5.

Six different strategies of louvers shading are chosen and reported in the following Table 9.

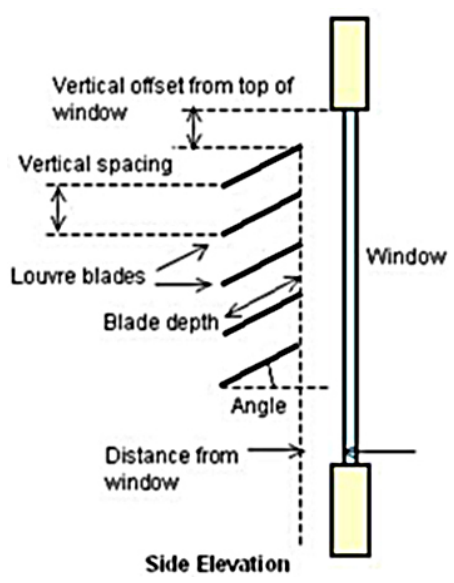

Fig. 5. Drawing of louvers geometry

Table 9. Louvers shading system strategies

\begin{tabular}{|c|c|c|c|c|c|c|}
\hline 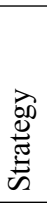 & 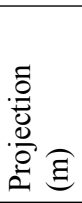 & $\stackrel{\frac{0}{60}}{\stackrel{4}{<}}$ & 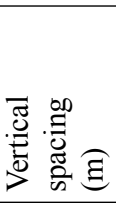 & 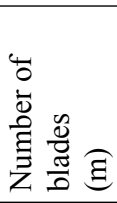 & 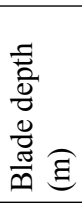 & 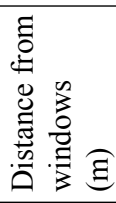 \\
\hline 1 & 0.5 & 0 & 0.35 & 10 & 0.2 & 0.3 \\
\hline 2 & & 15 & 0.35 & 10 & 0.2 & 0.3 \\
\hline 3 & & 30 & 0.25 & 14 & 0.2 & 0.3 \\
\hline 4 & 1.0 & 0 & 0.7 & 5 & 0.7 & 0.3 \\
\hline 5 & & 15 & 0.7 & 5 & 0.7 & 0.3 \\
\hline 6 & & 30 & 0.7 & 5 & 0.7 & 0.3 \\
\hline
\end{tabular}

\section{Results}

Simulation results are presented separately for each parameter and for different climate. The overall annual primary energy requirement is the value that is mainly analysed, because it is used to judge energy performance of the building, but also analysis of the final energy demand balances is presented to show where problems arise and potential saving exist.

\section{Glazing U-value}

The simulations carried out for the windows U-value show an intense variation in the heating and cooling loads for both Italy and Lithuania, while other parameters were steady as the lighting and the internal equipment energy requirements.

As it is shown in the Fig. 6, glazing U-value variation has strong influences on the heating demand reduction. Obviously, more in Lithuania than in Italy, in which the 


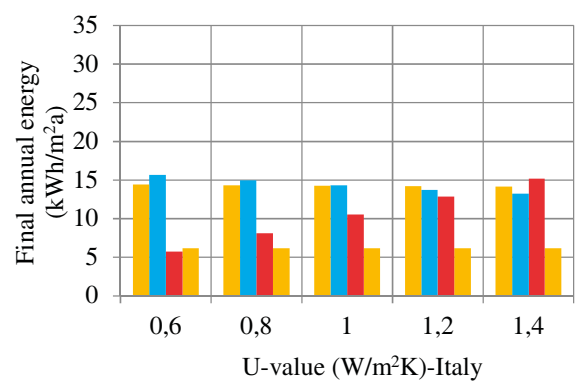

a)

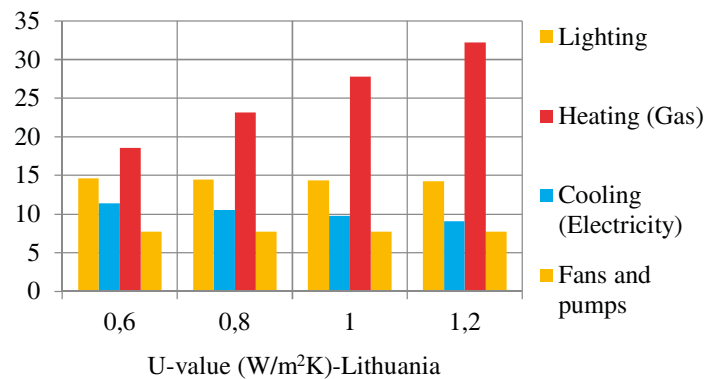

b)

Fig. 6. A final energy demand depending on the glazing U-values: (a) Italy and (b) Lithuania study case

humid continental climate requires much more energy for the heating. Still, in Italy the improvement of glazing U-value from 1.4 to $0.6 \mathrm{~W} / \mathrm{m}^{2} \mathrm{~K}$ implicates a reduction of the heating energy requirement from 15 to $5 \mathrm{kWh} / \mathrm{m}^{2} \mathrm{a}$.

The improvement of the windows U-value increases the annual cooling energy demand. With very low U-values, the temperature increment could be slightly reduced in the internal offices, but during the night, the low U-value impedes the release of the stored heat.

It can be noticed that the heating energy reduction is much more higher than the cooling energy increment when the glazing U-value is improved. In the case of Lithuania, the use of the best performing windows is definitely compulsory, if the total energy demand needs to be lowered.

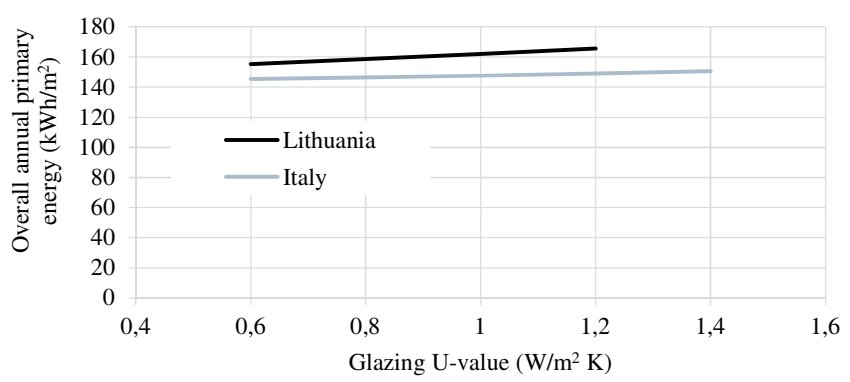

Fig. 7. Overall annual primary energy requirement depending on glazing U-value for the case studies
On the other hand, in Italy, the cooling demand is high, and it is clear that it cannot be controlled nor by reducing glazing U-value, neither by increasing it. It can be useful to keep a low windows U-value in order to reduce the heating demand, while trying to control the cooling demand with other parameters such as SHGC or shading.

In conclusion, in terms of primary energy, the total savings from the standard U-value to the best case are around 4 and 6\% for Italy and Lithuania respectively (Fig. 7) - in both cases it can be considered as low and obviously window U- value potential for savings is almost exhausted.

\section{SHGC and VT}

The SHGC and VT are strongly influencing three main energy demand components: heating, cooling and lighting energy. For both Italian and Lithuanian case studies, the demand trends are similar (Fig. 8): the lower the SHGC, the lower the cooling and the auxiliary (fans and pumps) energy demand, while the lighting and the heating requirement are increasing.

According to the primary energy factor, it is better to save cooling energy than heating one. This brings to the conclusion that in both Italy and Lithuania, the optimal SHGC to reduce the global primary energy is around 0.1-0.3. (Fig. 9(a)). In this case, the primary energy savings

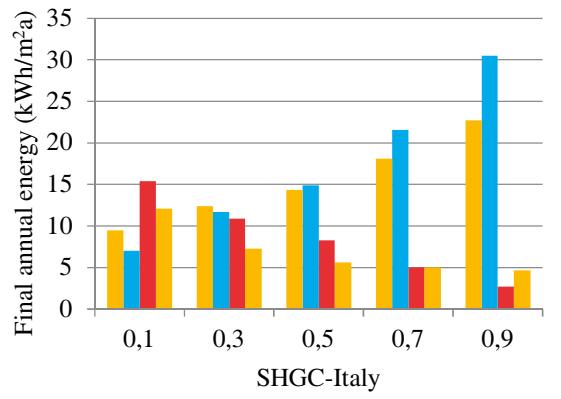

a)

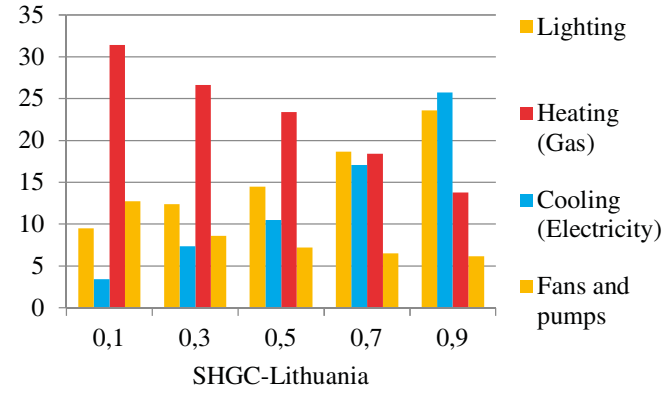

b)

Fig. 8. Final energy demand depending on SHGC: (a) for Italy and (b) for Lithuania 


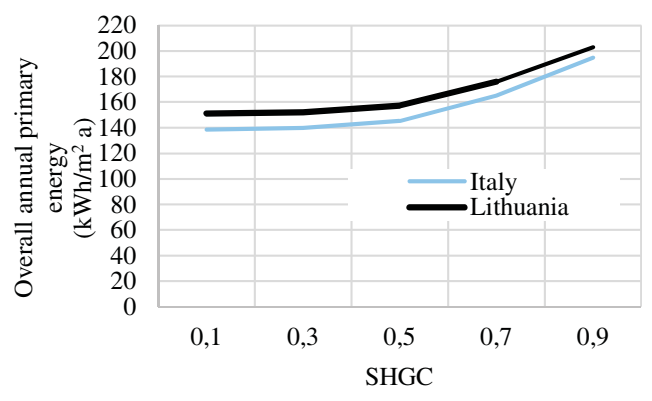

a)

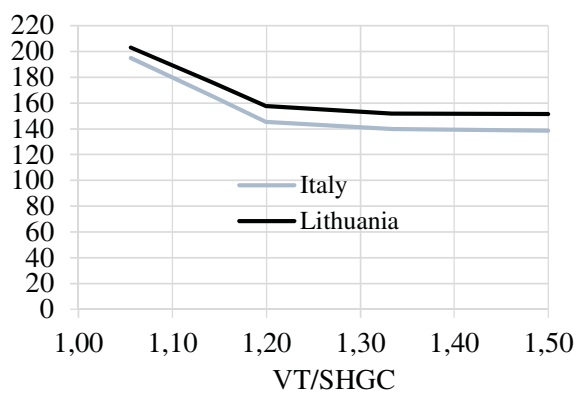

b)

Fig. 9. Overall annual primary energy demand depending on: (a) SHGC and (b) VT/SHGC

between the best and the worst case are 29\% for Italy and $25 \%$ for Lithuania. Again, this is a strong evidence of the fact that solar gain dramatically influence a totally glazed facade: without prevention against the solar gain, the primary energy demand is around $190-200 \mathrm{kWh} / \mathrm{m}^{2} \mathrm{a}$, while with the best solution the primary energy requirement is around $140-150 \mathrm{kWh} / \mathrm{m}^{2} \mathrm{a}$. Furthermore, the energy savings in Italy are higher; this shows that in a warmer climate protection against solar gain is extremely necessary.

Finally, it is worth to notice that the higher the VT/SHGC the lower the overall annual primary energy (Fig. 9(b)). The causes of this result are clear: high values of VT/SHGC imply daylight avoiding the income of solar gain, thus, energy savings on the artificial lighting with slight variation on cooling loads. Again, this result proves what was mentioned in 1.3.4 paragraph: the ideal case is to have as high as possible VT coefficient and as small as possible SHGC value.

\section{Shading}

Overhang. Simulations were performed in two steps: overhangs only in the South façade, firstly, and overhangs for East, South and West facades later. Here, only the second step is presented (Fig. 10) because the first one does not bring significant improvements (Fig. 11).
As seen from Fig. 10, the deeper is the overhang, the lower is the cooling load, but on the other hand - heating and lighting energy increases. The cooling demand decrease is due to the summer shading, but as can be seen this has a negative effect, since during the winter the solar radiation is stopped, causing the heating and lighting increase. Furthermore, the relative decrease or increase of energy requirement in each area has mostly the same trends for the both cases. This means that this type of shading does not make any difference depending on the climate.

Focusing on the overall primary energy consumption (Fig. 11), results show that if shading is applied only on the southern facade, the effect is slight for the Lithuanian case study, while it is almost negligible in the Italian one. On the other hand, in the case of overhangs applied in East, South and West facades the decrease of annual primary energy is evident. As it can be seen from the line slope, the decrease of global energy is equal in both the case studies: around $7 \%$ in both cases. But for the offices overhangs of $3 \mathrm{~m}$ depth is rather unusual solution, therefore it can be concluded this type of shading is not recommended for offices both in warm and cold climates.

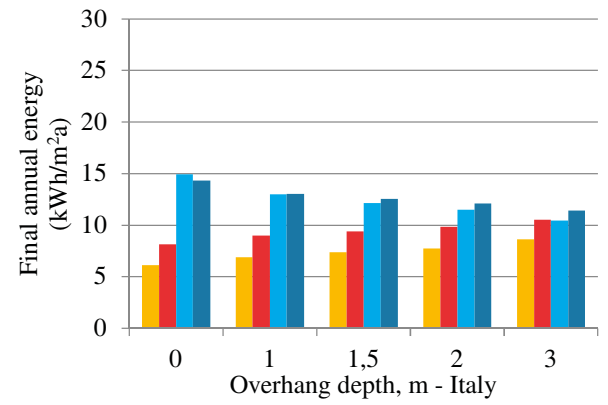

(a)

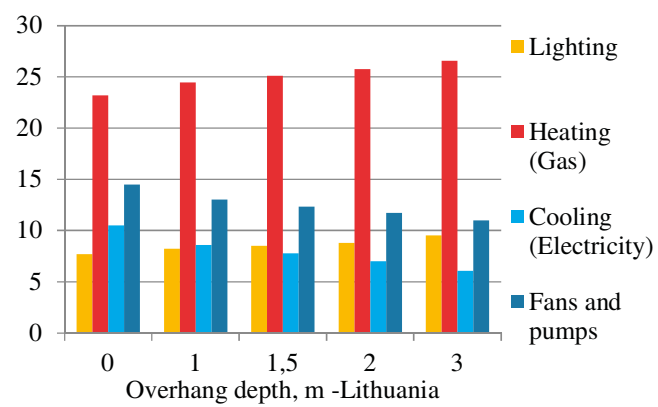

(b)

Fig. 10. Final energy demand depending on overhang shading strategy: (a) Italy and (b) Lithuania 


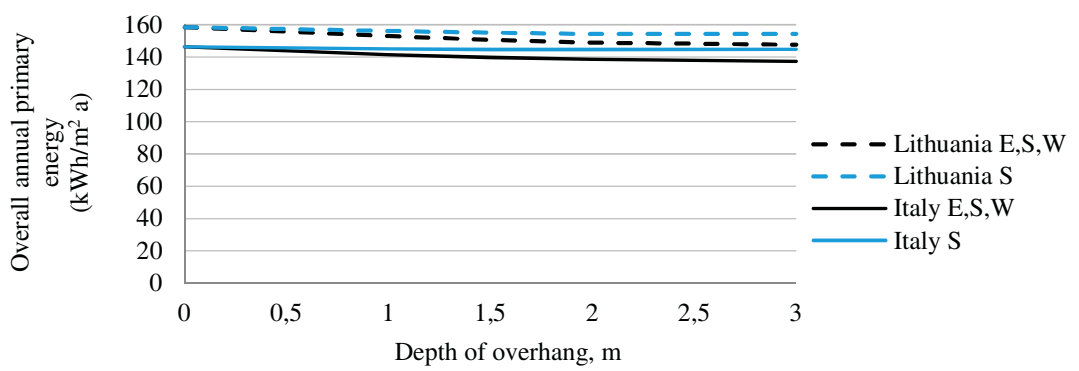

Fig. 11. Overall annual primary energy demand depending on overhang shading strategy for the study cases

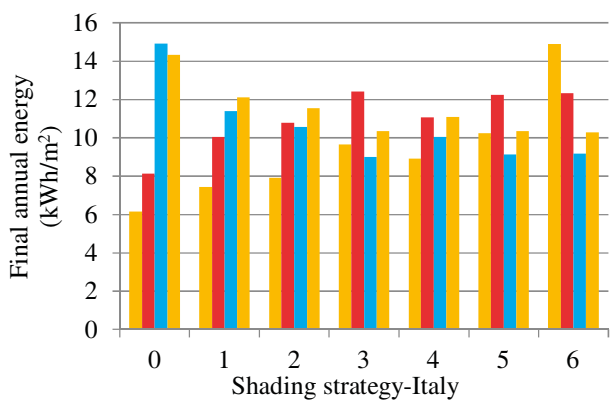

(a)

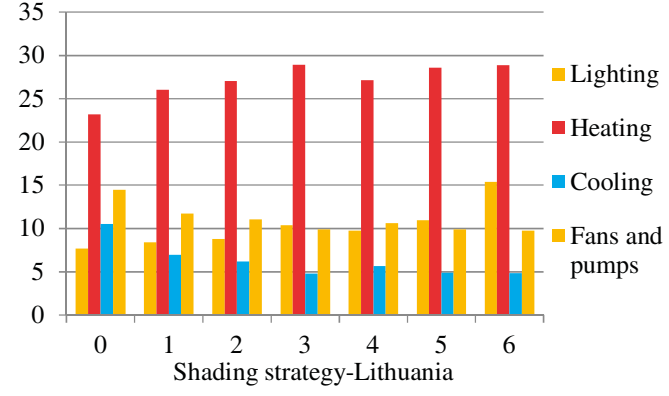

(b)

Fig. 12. Final energy demand depending on louvers shading strategy: (a) Italy and (b) Lithuania

\section{Louvers}

Final energy demand for each louvers strategy is presented in Fig. 12. Strategy number 3, 5, 6 are the best for cooling reduction in Lithuania, while in Italy the best for cooling reduction is number 3 . In both cases, strategy number 6 has too much energy requirement for lighting compared with the other ones. Strategy number 1 would be perfect for lighting energy, but on the other hand, it allows more solar radiation to income, thus the cooling requirement is still high.

In terms of overall primary energy (Fig. 13), the most efficient strategy is number 3 for Italy while number 2 and 3 are equally efficient for the case of Lithuania. In the range of louvers alternatives, the heating requirement does not change significantly; while the best solution is that one which can better decrease the cooling value, without darken dramatically the offices' space. In analogy with the overhangs the peaks of energy savings are around $7 \%$ for both cases.

Table 10 summarizes possible savings for all strategies analysed. It is obvious, that significant effect is reached just changing glazing properties. U-value decrease has low energy saving potential and analysed shading strategies as well. Better effect from shading might be expected if

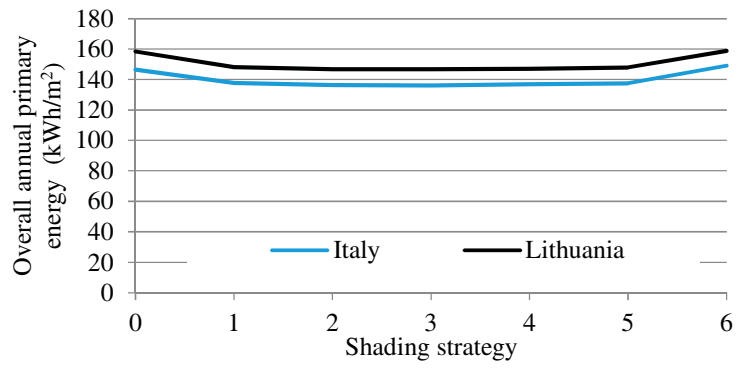

Fig. 13. Overall annual primary energy demand depending on overhang shading strategy

shading would have automatically control - this would enable to protect building from solar heat gains in summer, but enable entering them in winter, thus avoiding negative effects and increasing savings.

Table 10. Savings potential of overall annual primary energy demand, \%

\begin{tabular}{|l|c|c|c|c|}
\hline \multirow{2}{*}{ Location } & \multirow{2}{*}{$\begin{array}{c}\text { Glazing } \\
\text { U-value }\end{array}$} & \multirow{2}{*}{$\begin{array}{c}\text { SHGC and } \\
\text { VT }\end{array}$} & & \multicolumn{2}{|c|}{ Shading } \\
\cline { 4 - 5 } & & & Overhang & Louvres \\
\hline Italy & 4 & 29 & 6 & 7 \\
\hline Lithuania & 6 & 25 & 6 & 7 \\
\hline
\end{tabular}


Combination of the optimal parameters values

In both cases the best U-value found is $0.6 \mathrm{~W} / \mathrm{m}^{2} \mathrm{~K}$. For what concern the shading, louvers strategy is preferred and strategy number 3 is chosen as optimal for both cases. The case of choosing SHGC and VT is more complicated. In fact, the most efficient SHGC value would be 0.1 for the Italian case and $0.1-0.3$ for the Lithuanian one. However, the SHGC influence analysis was performed in absence of shading system, therefore simulation is repeated to establish the optimal value of SHGC and VT with the presence of the most efficient shading system (strategy 3).

In Fig. 14 can be seen that the best SHGC value for both locations is 0.5 , when U-value is $0.6 \mathrm{~W} / \mathrm{m}^{2} \mathrm{~K}$ and shading strategy with louvers is 3 .

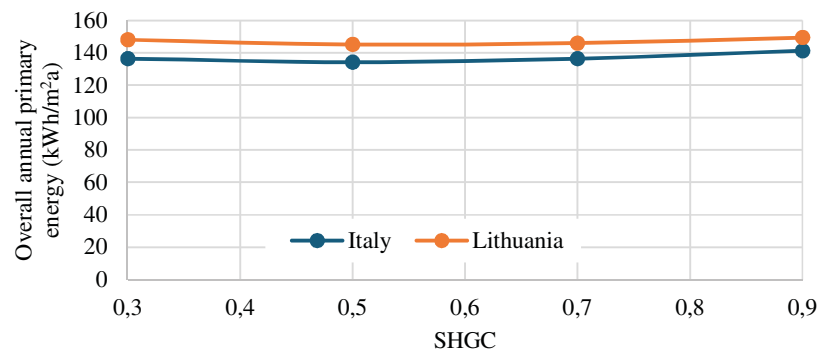

Fig. 14. Global annual primary energy depending on the SHGC when optimal shading system strategy is on (strategy)

Summarized results are given in Table 11. Despite the differences in finally energy balance for different locations, the overall primary energy demand difference is not as high as expected (just around 6\%) and in general analysed energy efficiency measures give nearly the same effect.

Table 11. Final energy and overall primary energy in $\mathrm{kWh} / \mathrm{m}^{2}$ for the most efficient solution

\begin{tabular}{|c|c|c|c|c|c|c|}
\hline & \multicolumn{5}{|c|}{ Final energy } & \multirow[b]{2}{*}{$\begin{array}{c}\text { Primary } \\
\text { energy }\end{array}$} \\
\hline & 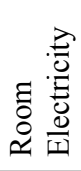 & 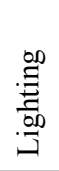 & 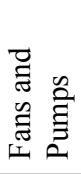 & 恕 & ن & \\
\hline Italy & 20 & 8.9 & 10.3 & 9.9 & 9.4 & 132.0 \\
\hline Lithuania & 20 & 9.7 & 9.9 & 24.3 & 5.2 & 140.3 \\
\hline
\end{tabular}

\section{Conclusions and discussion}

Simulation of different alternatives both for Italian and Lithuanian climates has shown that for totally glazed office building glazing U-value has small potential in reduction of primary energy demand, because difference between values required by the standard and best available on the market is decreasing. Estimated overall primary energy savings are 4 and $6 \%$ in warm and cold climates respectively.

The highest impact on buildings energy efficiency is done by glazing properties - SHGC and VT. That is an evidence that the solar gain are the most critical variable in a total glazed building. Anyway, the reduction could achieve peaks of $30 \%$ in the warmer climate only if $0.1-0.2$ SHGC values are used. Such values cause high investments and higher artificial lighting costs. Furthermore, many of the glazed facades advantages would be lost, such as the transparency and daylighting. Therefore it is more rational to look at the ratio VT/SHGC, when choosing a glazing. Results have shown that there is a significant drop in energy demand from VT/SGHC value 1.0 to 1.2 and from 1.2 to 1.5 energy saving potential is almost stable. This brings to the conclusions that SHGC of 0.5 and VT of 0.6 could be an efficient choice both in terms of daylighting and energy efficiency, it also does not require high investments into glazing.

Analysis of the shading alternatives has shown that louvers should be preferred in place of overhangs. With the best louvers strategy, the energy savings in the warmer climate are still equal to the colder one (7\%). It correspond to results given by Bellia et al. (2013), while for savings values beyond $10 \%$ a dynamical shading system is required (Nielsen et al. 2011).

Summarizing the results it can be stated, that despite differences in energy balance structure, different analysed envelope improvement measures give very similar results both for warm and cold climate. The most important envelope parameter is solar heat gain coefficient, but ratio between VT and SHGC must be taken into account. $\mathrm{U}$ value as well as static external shading has low energy saving potential for both climates. In the last step of the calculations, all the optimal values of the parameters analysed were combined for the two cases analysed in order to obtain the two ideal optimal buildings in terms of primary energy consumption. Results show that for the analysed building just with optimisation of the envelope properties it is possible to decrease primary energy demand up to $130 \mathrm{kWh} / \mathrm{m}^{2} \mathrm{a}$ for the Italian and $140 \mathrm{kWh} / \mathrm{m}^{2} \mathrm{a}$ for the Lithuanian climate. It is necessary to highlight that the study focuses only on the envelope parameters and does not take into account usage of renewables. This means that with the use of renewable energy, e.g. a grid PV system on the roof of the building, the primary energy demand could be dramatically lowered. 


\section{References}

Ascione, F.; De Masi, R. F.; de Rossi, F.; Ruggiero, S.; Vanoli, G. P. 2016. Optimization of building envelope design for nZEBs in Mediterranean climate: performance analysis of residential case study, Applied Energy 183: 938-957. https://doi.org/10.1016/j.apenergy.2016.09.027

Bellia, L.; De Falco, F.; Minichiello, F. 2013. Effects of solar shading devices on energy requirements of standalone office buildings for Italian climates, Applied Thermal Engineering 54(1): 190-201.

https://doi.org/10.1016/j.applthermaleng.2013.01.039

Bruno, R.; Arcuri, N.; Carpino, C. 2015. The passive house in Mediterranean area: parametric analysis and dynamic simulation of the thermal behaviour of an innovative prototype, Energy Procedia 82: 533-539.

https://doi.org/10.1016/j.egypro.2015.11.866

Buildup European Journal. 2017. The edge: Amsterdam office building with highest BREEAM score to date [online], [cited 11 January 2017]. Available from Internet: http:// www.buildup.eu/en/practices/cases/edge-amsterdam-officebuilding-highest-breeam-score-date

Buonomano, A.; De Luca, G.; Montanaro, U.; Palombo, A. 2016. Innovative technologies for NZEBs: an energy and economic analysis tool and a case study of a non-residential building for the Mediterranean climate, Energy and Buildings 121: 318-343. https://doi.org/10.1016/j.enbuild.2015.08.037

BREEAM. 2016. Breeam international new construction 2016 [online], [cited 06 April 2017]. Available from Internet: http://www.breeam.com/new-construction

Designbuilder. 2015. Design Builder Help 3.4 [online], [cited 25 April 2017]. Available from Internet: http://www.designbuilder.co.uk/helpv3.4/

De Carli, M.; De Giuli. 2007. Edifici vetrati a basso consumo [online], [cited 15 April 2017]. Available from Internet: http://www.enea.it/it/Ricerca_sviluppo/documenti/ricerca-disistema-elettrico/condizionamento/allegati_rse08/mo07.pdf

EN 15251:2008 - Indoor Environmental Input Parameters for Design and Assessment of Energy Performance of Buildings Addressing Indoor Air Quality, Thermal Environment, Lighting and Acoustics, 2008.

EN ISO 13790:2008 - Energy performance of office buildings Calculations of energy use for space heating and cooling.

Etzion, Y.; Erell, E. 2000. Controlling the transmission of radiant energy through windows: a novel ventilated reversible glazing system, Building and Environment 35(5): 433-444. https://doi.org/10.1016/S0360-1323(99)00039-6

European Parliament, EPBD Recast e Energy Performance of Buildings Directive. Directive 2010/31/EU of the European Parliament and of the Council of the European Union, European Parliament, 2010.

Feng, G.; Sha, S.; Xu, X. 2016. Analysis of the building envelope influence to building energy consumption in the cold regions, Procedia Engineering 146: 244-250. https://doi.org/10.1016/j.proeng.2016.06.382

Goia, F. 2016. Search for the optimal window-to-wall ratio in office buildings in different European climates and the implications on total energy saving potential, Solar Energy 132: 467-492. https://doi.org/10.1016/j.solener.2016.03.031
Grynning, S.; Time, B.; Matusiak, B. 2014. Solar shading control strategies in cold climates - heating, cooling demand and daylight availability in office spaces, Solar Energy 107(7465): 182-194. https://doi.org/10.1016/j.solener.2014.06.007

Hernandez, O. 2011. Design, planning and actors of Elithis Tower in Dijon, France, Rehva Journal May(2011): 53-57.

IINAS. 2015. Development of the primary energy factor of electricity generation in the EU-28 from 2010-2013 [online], [cited 06 April 2017]. Prepared for EHPA. Uwe R. Fritsche, Hans-Werner Greb. Darmstadt, March, 2015. Available from Internet: http://iinas.org/tl files/iinas/downloads/GEMIS/2015_PEF_EU-28_Electricity_2010-2013.pdf

Inanici, M. N.; Demirbilek, F. N. 2000. Thermal performance optimization of building aspect ratio and South window size in five cities having different climatic characteristics of Turkey, Building and Environment 35(1): 41-52. https://doi.org/10.1016/S0360-1323(99)00002-5

Lylykangas, K. 2009. Shape factor as an indicator of heating energy demand, in Proceedings of the 15th International Wood Construction Conference (IHF), 2009: Sweden [online], [cited 05 April 2017]. Available from internet: http:// www.forum-holzbau.com/pdf/ihf09_Lylykangas.pdf

Iasparra, G. 2009. Grattacielo Intesa San Paolo: consumi tripli per il riscaldamento, Eco dalle città journal October (06-2009) [online], [cited 02 April 2017]. Available from Internet: http:// www.ecodallecitta.it/notizie/100412/grattacielo-intesa-sanpaolo-consumi--tripli-per-il-riscaldamento/

Kong, X.; Liu, S.; Yang, H.; Zhong, Y.; Qi, C. 2016. An experimental study of all-season operation strategy for a respiration-type double-layer glass curtain wall system in cold zone of China, Building and Environment 97: 166-176. https://doi.org/10.1016/j.buildenv.2015.11.030

Kontoleon, K. J.; Bikas, D. K. 2002. Modeling the influence of glazed openings percentage and type of glazing on the thermal zone behavior, Energy and Buildings 34(4): 389-399. https://doi.org/10.1016/S0378-7788(01)00125-6

Lam, T. C.; Ge, H.; Fazio, P. 2015. Impact of curtain wall configurations on building energy performance in the perimeter zone for a cold climate, Energy Procedia 78: 352-357. https://doi.org/10.1016/j.egypro.2015.11.665

LEED. 2016. Guide to leadership in economy and environmental design certification [online], [cited 15 May 2017 ]. Available from Internet: https://www.usgbc.org/cert-guide

Liu, M.; Wittchen, K. B.; Heiselberg, P. K. 2015. Control strategies for intelligent glazed façade and their influence on energy and comfort performance of office buildings in Denmark, Applied Energy 145: 43-51.

https://doi.org/10.1016/j.apenergy.2015.02.003

Motuzienè, V.; Juodis, E. S. 2010. Simulation based complex energy assessment of office building fenestration, Journal of Civil Engineering and Management 16(3): 345-351. https://doi.org/10.3846/jcem.2010.39

Nielsen, M. V.; Svendsen, S.; Jensen, L. B. 2011. Quantifying the potential of automated dynamic solar shading in office buildings through integrated simulations of energy and daylight, Solar Energy 85(5): 757-768. https://doi.org/10.1016/j.solener.2011.01.010 
Palmero-Marrero, A. I.; Oliveira, A. C. 2006. Evaluation of a solar thermal system using building louvre shading devices, Solar Energy 80(5): 545-554.

https://doi.org/10.1016/j.solener.2005.04.003

Poirazis, H.; Blomsterberg, Å.; Wall, M. 2008. Energy simulations for glazed office buildings in Sweden, Energy and Buildings 40(7): 1161-1170. https://doi.org/10.1016/j.enbuild.2007.10.011

Straube, J. 2008. Can highly glazed building façades be green [online], [cited 01 June 2017]. Available from Internet: https://buildingscience.com/documents/insights/bsi-006-canfully-glazed-curtainwalls-be-green -

Susorova, I.; Tabibzadeh, M.; Rahman, A.; Clack, H. L.; Elnimeiri, M. 2013. The effect of geometry factors on fenestration energy performance and energy savings in office buildings, Energy and Buildings 57: 6-13. https://doi.org/10.1016/j.enbuild.2012.10.035

Tzempelikos, A.; Athienitis, A. K. 2007. The impact of shading design and control on building cooling and lighting demand, Solar Energy 81(3): 369-382. https://doi.org/10.1016/j.solener.2006.06.015

Yu, J.; Tian, L.; Xu, X.; Wang, J. 2015. Evaluation on energy and thermal performance for office building envelope in different climate zones of China, Energy and Buildings 86: 626-639.

\section{ENERGIŠKAI EFEKTYVAUS ADMINISTRACINIO PASTATO SU DIDELIAIS ĮSTIKLINIMO PLOTAIS FASADO SPRENDINIAI ESANT SKIRTINGAM KLIMATUI}

\section{Scanferla, V. Motuzienė}

\section{Santrauka}

Straipsnyje pateikiamo tyrimo tikslas - parodyti kritinius daugiaaukščiu administracinių pastatų su dideliais įstiklinimo plotais atitvarų charakteristikų aspektus energinio efektyvumo požiūriu esant skirtingam klimatui. Buvo tiriami labiausiai țtaką energiniam efektyvumui darantys parametrai - šilumos perdavimo koeficientai U, šviesos ir visuminio saulès energijos praleisties koeficientų santykis VT/SHGC bei apsaugos nuo saulès priemonès ir optimalūs jų dydžiai. Buvo atliekama teorinio administracinio pastato Italijoje ir Lietuvoje analizè. Šios vietovès buvo parinktos Europos pietiniam ir šiauriniam klimatui reprezentuoti. Parinktas pastatas yra tipinès nesudètingos formos, su visiškai istiklintais fasadais. Pastato charakteristikų itaka vertinama kompleksiškai modeliuojant pastato metinius energijos poreikius taikant DesignBuilder programą, vertinimo kriterijus - metiniai pirminès energijos poreikiai. Rezultatai parode, kad pastatui su $100 \%$ fasado istiklinimo plotu nustatyti kritiniai aspektai yra: esant šaltam klimatui pagrindinè problema yra dideli atitvaru plotai, kuriems būdingas sąlygiškai didelis šilumos perdavimo koeficientas, lyginant su neskaidriomis atitvaromis, o esant šiltam klimatui reikia dèti pastangas, kad būtų sumažinti milžiniški šilumos pritèkiai, atsirandantys dèl saulès. Straipsnyje parodyta, kad vien optimizuojant atitvaru charakteristikas sudètinga pasiekti metinius pirminès energijos poreikius, mažesnius nei 130 ir $140 \mathrm{kWh} / \mathrm{m}^{2}$, esant Italijos ir Lietuvos klimatui atitinkamai. Tyrime nevertinamas atsinaujinančios energijos išteklių panaudojimas, kuris gali itin padidinti pastato energini naudingumą.

Reikšminiai žodžiai: administracinis pastatas, klimatas, energinis efektyvumas, atitvaros, stiklinis fasadas, apsauga nuo saulès. 